\title{
COMPARISON OF THE ANTIEMETIC EFFECTIVENESS BETWEEN GRANISETRON AND DEXAMETHASONE WITH ONDANSETRON AND DEXAMETHASONE IN ACUTE-PHASE CHEMOTHERAPY PATIENTS
}

\author{
Ria Fitrah Arfiani ${ }^{1}$, Dwi Hari Susilo ${ }^{2}$, Budi Suprapti ${ }^{1}$ \\ ${ }^{1}$ Department of Clinical Pharmacy, Faculty of Pharmacy, Universitas Airlangga \\ ${ }^{2}$ Division of Head and Neck Surgery, Deparment of Surgery, Faculty of Medicine, \\ Universitas Airlangga/Dr Soetomo Hospital
}

\begin{abstract}
ABSTRAK
Kondisi mual muntah dapat terjadi pada pasien yang mendapatkan kemoterapi yang disebut sebagai mual muntah akibat pemberian kemoterapi. Pemberian kombinasi Dexamethasone dan ondansetron atau granisetron merupakan manajemen terapi mual muntah fase akut pada sitostatika dengan resiko mual muntah tinggi. Pada studi literatur, granisetron memiliki farmakokinetik dan farmakodinamik yang lebih baik dibandingkan dengan ondansetron, sehingga dimungkinkan memiliki efek menekan mual muntah yang lebih tinggi daripada ondansetron. Penelitian ini bertujuan membandingkan efektivitas antiemetik granisetron dan Dexamethasone dengan ondansetron dengan Dexamethasone pada fase akut pasien kemoterapi. Penelitian dilakukan pada pasien yang mendapatkan kombinasi cisplatin-paclitaxel dan cisplatin-fluorouracil, double- blind dengan sampel pasien onkologi bedah kepala leher baru. Pengukuran kondisi mual muntah pada fase akut kemoterapi dilakukan dengan menggunakan metode Index of Nausea, Vomiting, and Retching (INVR). Pengamatan mual muntah dilakukan pada pasien selama 12 jam pertama setelah pemberian cisplatin dan dilakukan wawancara pada jam ke 12. Hasil menunjukkan bahwa tidak ada perbedaan efektivitas penenkanan mual muntah pada pemberian granisetron dan Dexamethasone dibandingkan pemberian ondansetron dan Dexamethasone pada fase akut pasien kemoterapi $(p=0,076)$. (FMI 2016;52:185-192)
\end{abstract}

Kata kunci: Granisetron, Ondansetron, Deksamethason, Fase akut, Cisplatin, Paclitaxel, Fluorouracil

\begin{abstract}
Nausea and vomiting may occur in patients receiving chemotherapy, a condition referred to as chemotherapy-induced nausea and vomiting. The provision of combined dexamethasone and ondansetron or granisetron is the therapeutic management of acute phase nausea and vomiting in cytostatics with a high risk of nausea and vomiting. Granisetron has been known to have better pharmacokinetics and pharmacodynamics compared to ondansetron, so it is possible to have nausea and vomiting suppressing effect higher than that of ondansetron. This study aimed to compare antiemetic effectiveness of granisetron and dexamethasone with ondansetron and dexamethasone in acute-phase chemotherapy patients. This study was conducted in patients who received the combination of cisplatin-paclitaxel and cisplatin-fluorouracil, double-blind, with samples comprised new head and neck surgical oncology patients. Measurement of nausea and vomiting during the acute phase of chemotherapy was conducted using Index of Nausea, Vomiting, and Retching (INVR). Observation of nausea and vomiting in the patients was done during the first 12 hours after administration of cisplatin and interviews were conducted on $h$ 12. Results showed that there was no difference in the effectiveness of nausea and vomiting suppression in the administration of granisetron and dexamethasone compared to ondanstron and dexamethasone in acute phase chemotherapy patients $(p=0.076)$. (FMI 2016;52:185-192)
\end{abstract}

Keywords: granisetron, ondansetron, dexamethasone, acute phase, cisplatin, paclitaxel, fluorouracil

Correspondence: Ria Fitrah Arfiani, Department of Clinical Pharmacy, Faculty of Pharmacy, Universitas Airlangga, Surabaya. Phone: 081336445118. e-mail: riafitrah@gmail.com

\section{INTRODUCTION}

Nausea and vomiting is a side effect of chemotherapy that often arise. This is because chemotherapy is toxic to cells of the GI tract enterochromaffin causing inflammation and involves a variety of mechanisms including 5- $\mathrm{HT}_{3}$ neurotransmitter, dopamine, NK-1, which causes nausea and vomiting center stimulation in the brain (Rojas \& Barbara 2012). According to the American Society of Clinical Oncology Clinical Practice (2011) suggested the use of antiemetics for chemotherapyinduced nausea and vomiting is a $5-\mathrm{HT}_{3}$ antagonist, a corticosteroid and an NK-1 receptor antagonists. Antiemetic was given based on levels of risk of nausea and vomiting associated with chemotherapy (Hesketh 2011). In this case, the level of risk of nausea and vomiting associated with chemotherapy were divided into four groups based sitostatika, namely: a high risk of $>90 \%$, $31-90 \%$ moderate risk, low risk of $10-30 \%$ and a minimum of $>10 \%$. Corticosteroids single therapy is 
recommended to chemotherapy by the risk of nausea and vomiting is low, a combination of corticosteroids and antagonist $5-\mathrm{HT}_{3}$ is for the therapy recommended chemotherapy with the risk of nausea and vomiting being, and at the risk of nausea and vomiting higher recommended a combination of antagonist $5-\mathrm{HT}_{3}$, corticosteroids, and the NK-1 receptor antagonists.

The combined use of cisplatin-paclitaxel and cisplatin5fluorouracil in the case of head neck surgical oncology at the inpatient section Head Neck Surgery and chemo room Sukardja Hospital Dr. Soetomo quite a lot. The combination sitostatika cause nausea and vomiting with high risk, so the management of nausea and vomiting treatment is given is a combination of $5-\mathrm{HT}_{3}$ antagonist, corticosteroid, and the NK-1 receptor antagonists. Antiemetic corticosteroids recommended is deksamethason because it is more glucocorticoids, while the $5-\mathrm{HT}_{3}$ antagonist is recommended ondansetron, granisetron, palonosentron, dolasetron, tropisetron, or ramosetron (Hesketh 2011). There are 2 antiemetic 5$\mathrm{HT}_{3}$ antagonist ondansetron and the outstanding field that granisetron at a price not much different. Differences in pharmacokinetics and pharmacodynamics of ondansetron and granisetron affect its effectiveness in reducing nausea and vomiting due to chemotherapy. Ondansetron has a half-life ( $t$ 1/2) 6 hours, with $70 \%$ protein binding, in hepatic metabolism and eliminated mostly by feces and only $<5 \%$ through the urine. While granisetron, duration of action (DOA) 24 hours, $t 1 / 2$ to 9 hours iv, bonding with protein $65 \%$, on the basis hepatic metabolism and elimination via urine and feces (AHFS, 2011). Pharmacokinetic differences lead to affect the time of administration. Ondansetron is given twice a day and granisetron given the day only one (Basch et al, 2011). In terms of pharmacodynamics, ondansetron and granisetron binding affinity to the $5-\mathrm{HT}_{3}$ receptor that is distinct PKI 8.19 and 8.91. Granisetron only has specific binding to the $5-\mathrm{HT}_{3}$ while ondansetron has ties with other receptors, namely $5-\mathrm{HT}_{1 \mathrm{~b}}, 5-\mathrm{HT}_{1 \mathrm{C}}, \alpha 1$-adrenergic, and $\mu$-opioid receptor.

\section{MATERIALS AND METHODS}

This study was an experimental study using simple randomization. Inclusion criteria of the study sample are surgical patients KL new oncology, receiving chemotherapy with a high risk of nausea and vomiting combination of cisplatin-paclitaxel and cisplatin-fluorouracil, age range 20-60 years and received premedication combination antiemetic granisetron and ondansetron and dexamethasone or dexamethasone. Exclusion criteria in this study were patients with a history of gastrointestinal disorders, patients with a history of kidney disease stage 3,4 , and 5 , patients with a history of liver disease and patients with metastases to the brain. Criteria drop out is the inclusion of patients with the condition of an allergic reaction or hypersensitivity due deksamethason, ondansetron and granisetron, or other medications used during the study.

The study was conducted in March 2015 - January 2016 at the Hospital Dr. Soetomo with a total sample of 31 patients. The sampling technique with consecutive samplings. Samples are grouped into two, namely the ondansetron-dexamethasone and granisetron-dexamethasone group. The allocation of subjects in each group is done by order of odd and even numbers. Then the determination of treatment received in groups of odd and even simple randomization method is to use the currency. Determination of the treatment received by the patient sample is a double-blind manner. Patients who meet the criteria of the sample, chemotherapy is given in accordance with standard operating procedures Head Neck Surgery. Award premedication is antiemetic ondansetron $8 \mathrm{mg}$ twice a day while granisetron $1 \mathrm{mg}$ once a day. Observations nausea, vomiting performed for 12 hours, beginning after the administration of cisplatin. At the 12th, conducted interviews to patients with the method of measurement Index of Nausea, vomiting and Retching (Rhodes, 1996, Brearley, 2008, Kim et al, 2007, Wood et al 2010). Then to compare the effectiveness of granisetron and ondansetron and dexamethasone with dexamethasone do different test.

\section{RESULTS}

Table 1. Demographic Characteristics of Patients

\begin{tabular}{lcc}
\hline \multicolumn{2}{c}{ Demographic Characteristics of Patients } \\
$\begin{array}{l}\text { Ondansetron- } \\
\text { Dexamethasone }\end{array}$ & $\begin{array}{c}\text { Granisetron- } \\
\text { Dexamethasone }\end{array}$ \\
\hline N total samples & 17 & 14 \\
Gender & 12 & 10 \\
Male & 5 & 5 \\
$\quad$ Female & 5 & 5 \\
N Cisplatin-Paclitaxel & 12 & 9 \\
N Cisplatin-5 Fluorouracil & & \\
\hline
\end{tabular}

From the measurement results obtained INVR nausea and vomiting with the clinical picture of the condition of nausea, vomiting without removing any and vomiting with their respective assessment parameters. Table 2 shows the percentage of nausea profile in a group granisetron and ondansetron-dexamethasone-dexamethasone, the data showed granisetron-dexamethasone combination has a percentage of the number 0 is greater than ondansetron-dexamethasone on the three parameters of frequency, duration and severity. Table 3 shows the percentage of the profile without issuing any vomiting (retching) in a group-dexamethasone and 
granisetron ondansetron-dexamethasone, the data showed, ondansetron-dexamethasone combination has the numbers 0 percentage greater than granisetrondexamethasone in both frequency and severity parameters. Table 4 shows the percentage of profiles vomiting that occurs in group-dexamethasone and granisetron ondansetron-dexamethasone, the data shows the number 0 more represented by granisetron-dexa-methasone group than in the group of ondansetron-dexamethasone, in frequency, many, or severity.

At the score of INVR method, the effectiveness of nausea and vomiting are divided into 5 categories. The first category is not happening nausea and vomiting with INVR value $=0$. The second category is nausea vomiting with INVR value $=1-8$. The third category is nausea and vomiting being the value INVR $=9-16$. The fourth category is nausea vomiting weight to the value INVR $=17-24$. The fifth category is extremely severe nausea and vomiting with a value INVR $=24-32$. From the results, the percentage of comparative effectiveness of antiemetic ondansetron and granisetron in combination with dexamethasone in each category (Figure 1). In the ondansetron-dexamethasone group, 53\% did not happen nausea and vomiting, and $47 \%$ were mild nausea, vomiting. While in the granisetron-dexamethasone group obtained $64 \%$ do not occur nausea, vomiting and $29 \%$ were mild nausea, vomiting. In different test, because the data are not normally distributed then used a different test by using the MannWhitney. The results showed that there is no difference in effectiveness in reducing nausea and vomiting in the administration of granisetron and dexamethasone compared to administration of ondansetron and dexamethasone in the acute phase of chemotherapy patients with a high risk of nausea and vomiting $(\mathrm{p}=0.076)$ (Figure 1).

Table 2. Profile Nausea Based on the frequency, duration and severity On Giving Ondansetron and Dexamethasone with Granisetron and Dexamethasone

\begin{tabular}{ccc}
\hline \multirow{2}{*}{ Parameter } & $\begin{array}{c}\text { Ondansetron and } \\
\text { Dexamethasone (\%) }\end{array}$ & $\begin{array}{c}\text { Granisetron and } \\
\text { Dexamethasone (\%) }\end{array}$ \\
\cline { 2 - 3 } Nrequency & \multicolumn{2}{c}{ Nausea } \\
0 & 56 & 77 \\
1 & 31 & 15 \\
2 & 13 & 0 \\
3 & 0 & 8 \\
4 & 0 & 0 \\
Duration & & \\
0 & 56 & 77 \\
1 & 31 & 15 \\
2 & 13 & 0 \\
3 & 0 & 8 \\
4 & 0 & 0 \\
Severity & & \\
\hline
\end{tabular}

\begin{tabular}{lcc}
\hline 0 & 56 & 77 \\
1 & 25 & 15 \\
2 & 19 & 8 \\
3 & 0 & 0 \\
4 & 0 & 0 \\
\hline
\end{tabular}

Table 3. Profile Vomiting Without Removing Whatever (Retching) Based on Frequency and Severity In granting Ondansetron and Dexamethasone with Granisetron and Dexamethasone

\begin{tabular}{ccc}
\hline \multirow{2}{*}{ Parameter } & $\begin{array}{c}\text { Ondansetron and } \\
\text { Dexamethasone (\%) }\end{array}$ & $\begin{array}{c}\text { Granisetron and } \\
\text { Dexamethasone (\%) }\end{array}$ \\
\cline { 2 - 3 } Vomiting Without Removing Whatever \\
\hline Frequency & 94 & 86 \\
0 & 6 & 7 \\
1 & 0 & 7 \\
2 & 0 & 0 \\
3 & 0 & 0 \\
4 & & \\
Severity & 94 & 76 \\
0 & 6 & 7 \\
1 & 0 & 0 \\
2 & 0 & 0 \\
3 & 0 & \\
4 & &
\end{tabular}

Table 4. Profile Vomiting Based on Frequency, Lots/ number and severity On Giving Ondansetron and Dexamethasone with Granisetron and Dexamethasone

\begin{tabular}{ccc}
\hline Parameter & $\begin{array}{c}\text { Ondansetron and } \\
\text { Dexamethasone (\%) }\end{array}$ & $\begin{array}{c}\text { Granisetron and } \\
\text { Dexamethasone (\%) }\end{array}$ \\
\cline { 2 - 3 } Frequency & \multicolumn{2}{c}{ Nausea } \\
0 & 88 & 93 \\
1 & 6 & 7 \\
2 & 6 & 0 \\
3 & 0 & 0 \\
4 & 0 & 0 \\
Lots/number & & \\
0 & 88 & 93 \\
1 & 12 & 7 \\
2 & 0 & 0 \\
3 & 0 & 0 \\
4 & 0 & 0 \\
Severity & & \\
0 & 88 & 93 \\
1 & 12 & 7 \\
2 & 0 & 0 \\
3 & 0 & 0 \\
4 & 0 & \\
\hline
\end{tabular}

Further analysis used sitostatika influence the response of nausea and vomiting because in this study used two kinds of combinations sitostatika namely cisplatin-5 fluorouracil and cisplatin-paclitaxel. Figure 2 shows the percentage of nausea and vomiting caused by cisplatin-5 fluorouracil, with the number $\mathrm{n}$ in ondansetron-dexamethasone group were 12 patients and the number $\mathrm{n}$ in the granisetron group-dexamethasone was 9 . The inci- 
dent did not occur nausea and vomiting ondan-setrondexamethasone group together with granisetron- dexamethasone is $66.7 \%$. The same thing happened in the incidence of nausea and vomiting lightweight category is $33.3 \%$. While the incidence of nausea and vomiting on a combination of cisplatin-paclitaxel (Figure 3) on the provision of antiemetic granisetron and dexa- methasone with $\mathrm{n}=5$, show a good response that is $100 \%$ did not experience nausea and vomiting. While the administration of ondansetron and dexa-methasone with $\mathrm{n}=5$, the incident did not experience nausea and vomiting by $20 \%$ and the remaining $80 \%$ experiencing mild nausea and vomiting.

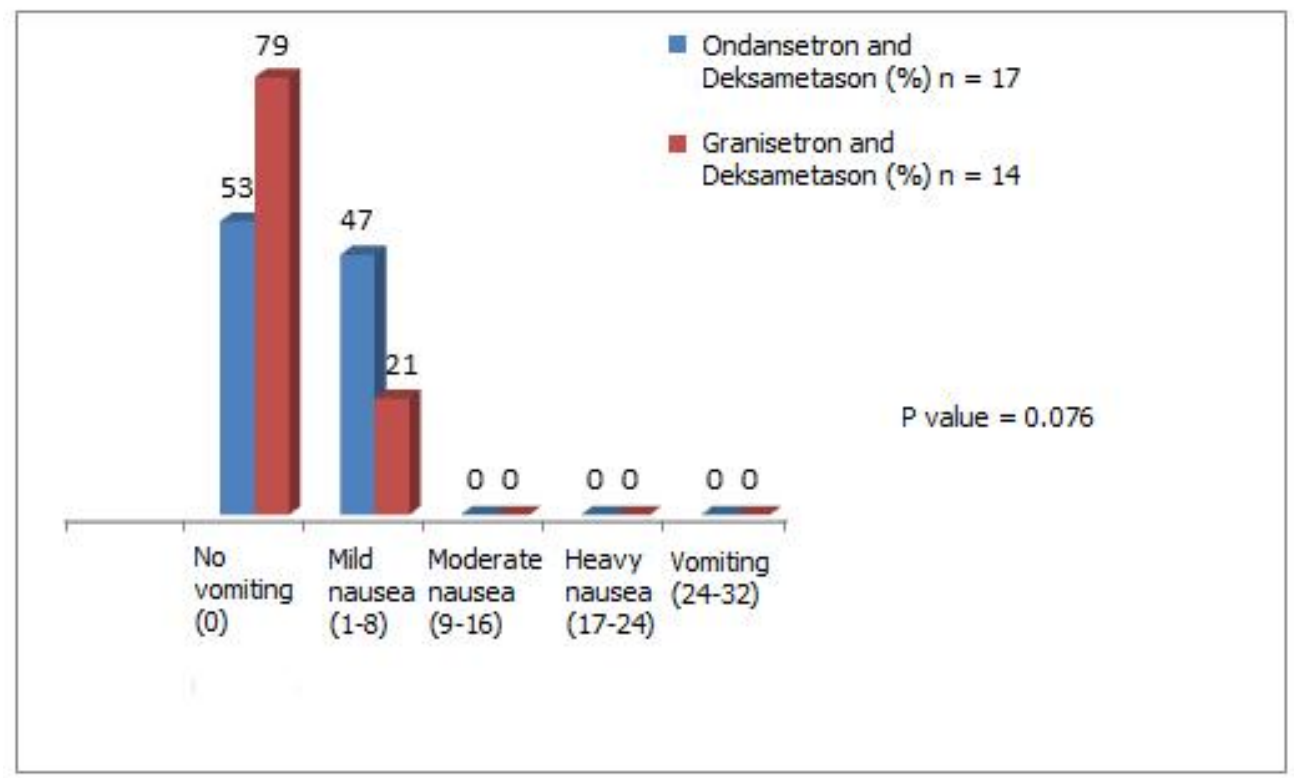

Fig. 1. Percentage of Comparative Effectiveness Granisetron antiemetics and dexamethasone with Ondansetron and Dexamethasone In Conditions Acute Phase Nausea Vomiting Chemotherapy Patients with High Risk of Nausea Vomiting



Figure 2. Percentage Nausea Vomiting occurred due to administration of cisplatin-5FU in each group. 


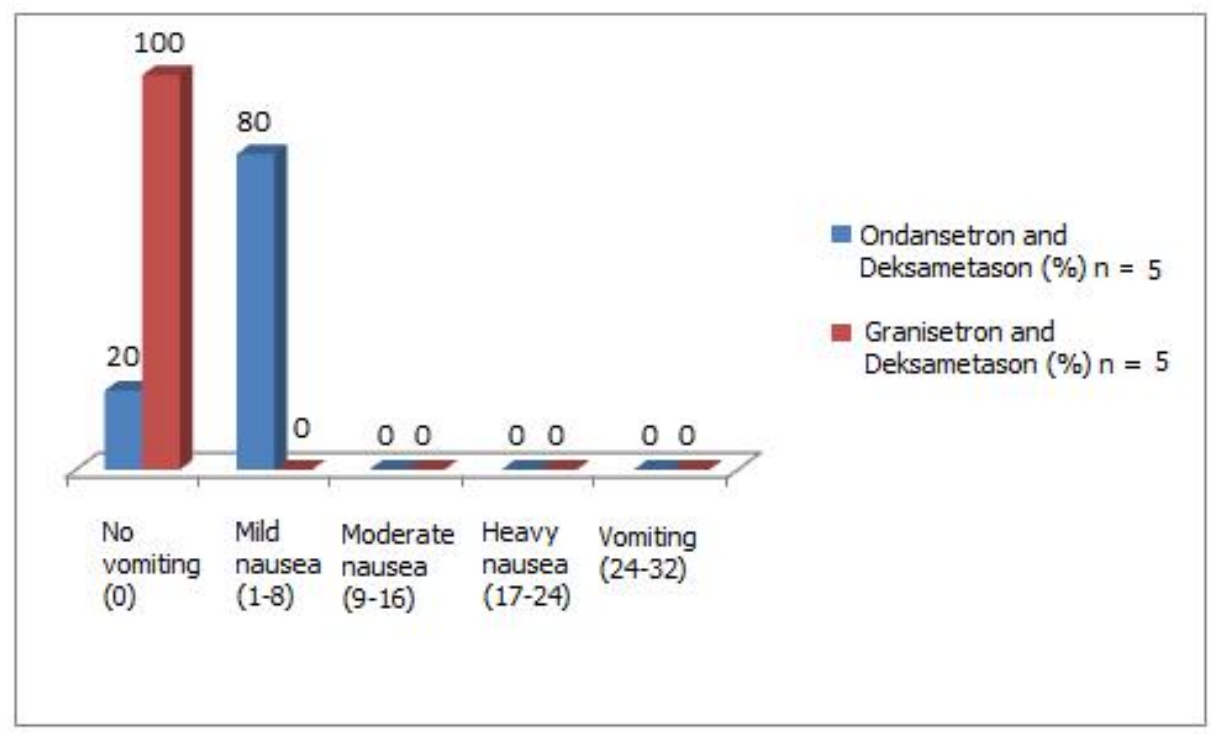

Figure 3. Percentage Nausea Vomiting occurred as a result of administration of Cisplatin-Paclitaxel in each group.

\section{DISCUSSION}

The combination of cisplatin-paclitaxel and cisplatinfluorouracil is sitostatika first line therapy in surgical oncology KL. Cisplatin has a degree of nausea and vomiting> $90 \%$, while sitostatika paclitaxel and fluorouracil have a degree of nausea and vomiting by $10 \%-30 \%$ (BCCA 2012). According to Hesketh, in addition to the degree of nausea and vomiting which is the distinctive character of the sitostatika, large doses of sitostatika also affect the response of nausea and vomiting. In addition, there are several other factors that affect namely: young and old age, a history of high alcohol consumption, and sex (Hesketh 2008). Cisplatin dose of $50 \mathrm{mg} / \mathrm{m} 2$ or more can increase the risk of nausea and vomiting by $90 \%$ in patients who did not receive prophylactic antiemetics (Schnell 2003). The use of cisplatin dose in surgical oncology KL is 100 $\mathrm{mg} / \mathrm{m} 2$ included in the category of high-dose cisplatin, so that it can improve the patient's response to nausea and vomiting.

Conditions chemotherapy-induced nausea and vomiting caused by sitostatika menginflamasi enterochromafin cells activate the gastrointestinal tract and abdominal vagal afferents. The incoming signal to the vagal afferents and forwarded to the CTZ is then processed in the dorsal vagal complex that activates the deep abdominal muscles, diaphragm, stomach, and esophagus to occur response nausea and vomiting (Rojas \& Barbara 2012). In addition to neuroanatomy, neuro-transmitters also have a role in triggering nausea and vomiting. A neurotransmitter that plays a major role is serotonin (5HT), substance P (SP), and dopamine. Ninety percent of serotonin is in the cells of the gastrointestinal tract enterochromafin (Katzung 2012). The neurotransmitter receptors of vagal afferent contained in the gastrointestinal tract (Feyer \& Jordan, 2011, Rojas \& Barbara 2012). When damage occurs gastrointestinal mucosa release of 5-hydroxytryptamine (5-HT) from enterochromaffin cells. The release of 5-HT innervation stimulates vagal afferents by binding to 5 -HT receptors. Substance P is released from the mucosa of the stomach, binds to NK-1 receptors and synergistic with 5HT in giving effect to the upper gastrointestinal tract to induce vomiting. In addition through the neurotransmitter networks, the material contained in cytotoxic chemotherapy may induce vomit blood directly in the center of CTZ area postrema. From CTZ signal will be transmitted to the vomiting center, causing nausea and vomiting response. The results of several studies the inhibition of dopamine performance does not give the inhibitory effect of nausea and vomiting in CINV (Rojas \& Barbara 2012).

In studies comparing the effectiveness of this antiemetics, used a wide dose is $1 \mathrm{mg}$ per antiemetic granisteron inj, inj ondansetron $8 \mathrm{mg}$ and $8 \mathrm{mg}$ dexamethasone, the recommended dose BCCA (Basch et al 2011, Hoskins 2012). The effectiveness of ondanetron and granisetron caused by several factors, namely pharmacokinetic and pharmacodynamic. In terms of pharmacokinetics, ondansetron has a half-life (t $1 / 2) 6$ hours, $70 \%$ protein binding, hepatic metabolized and eliminated mostly by feces and only less than 5\% through the urine. Granisetron, duration of action (DOA) 24 hours, $\mathrm{t} 1 / 2$ to 9 hours, the bond with 65\% protein, hepatic metabolized and eliminated through 
urine and feces (AHFS 2011). Pharmacokinetic differences affect the time of administration. Ondansetron is given twice a day and granisetron given the day only one (Basch et al, 2011). In terms of pharmacodynamics, ondansetron and granisetron binding affinity to the $5-\mathrm{HT}_{3}$ receptors are expressed differently by PKI consecutive 8.19 and 8.91 . Thus granisetron has the potential competitive binding with serotonin better compared with ondansetron. In addition, ondansetron has ties to other receptors, namely $5-\mathrm{HT}_{1 \mathrm{~b}}, 5-\mathrm{HT}_{1 \mathrm{C}}, \alpha 1$-adrenergic, and $\mu$-opioid receptor. So that ondansetron affinity divided to several other receptors than for $5-\mathrm{HT}_{3}$ receptor and potentially lead to the emergence of some of the side effects of medication. This is different from granisetron, which only has a binding affinity to the $5-\mathrm{HT}_{3}$ receptor (Schnell 2003). Headache, constipation, diarrhea, somnolence and asthenia are the side effects of $5-\mathrm{HT}_{3}$ receptor antagonists (Aapro 2004).

Chemically, the 5- $\mathrm{HT}_{3}$ receptor antagonists have a 3dimensional space steric molecule that plays a role in drug binding to receptors called farmakofor. The third farmakofor is aromatic ring, a carbonyl group, and form clusters specific to each drug. In determining the binding affinity to the receptor, the carbonyl group is not an farmakofor that is important, but the aromatic ring. Ondansetron has the aromatic core Carbazole by affinity binding to 5-HT receptors only 250 to 500 times. This is because ondansetron also has ties with other receptors, namely $5-\mathrm{HT}_{1 \mathrm{~b}}, 5-\mathrm{HT}_{1 \mathrm{c}}, \alpha 1$-adrenergic, and $\mu$ receptor. Granisetron has indazole core which has a binding affinity to the $5-\mathrm{HT}_{3}$ receptor 4000 to 40000 times higher than with other receptors (Mahesh et al 2004).

In this study, 31 samples sejumah KL surgical oncology patients newly receiving chemotherapy, 17 patients receiving ondansetron-dexamethasone and 14 others received granisetron and dexamethasone therapy. Age range were sampled adult category, in order to avoid factors that increase the risk of nausea and vomiting. Of the existing patient demographics (Table 1) shows that KL surgical oncology patients is most prevalent in men than women. Riskesdas data by 2010, the incidence of head neck cancer more common in men than women by a ratio of $3: 1$. From demographic data obtained in this study, the number of men more than women is $2: 1$.

Nausea and vomiting of measurements obtained using INVR some parameter descriptions. From the measurement of nausea, there are three parameters: frequency, duration and severity. 0 at the frequency parameter granisetron nausea largest at-dexamethasone group by $77 \%$, while in the ondansetron-dexamethasone group obtained a value of $56 \%$ (Table 1). It shows that granisetron-dexamethasone group gives emphasis to the response of nausea greater than ondansetron. Table 2 frequencies occur mild nausea (figure 1) and moderate (figure 2) experienced by patients receiving antiemetic ondansetron-dexamethasone. But at the frequency parameters severe nausea, granisetron-dexamethasone group obtained a percentage of $8 \%$. Something similar happened to the duration parameter. On the severity parameters obtained $8 \%$ with moderate nausea (figure 2) but not in conditions of severe nausea (3). The second data concluded that a combination antiemetic granisetron-dexamethasone combination can suppress nausea response greater than ondansetron-dexamethasone combination on all three parameters, frequency, duration and severity.

In Table 3 shows the profile without issuing any vomiting (retching), which consists of two parameters: the frequency and severity. In the ondansetrondexamethasone combination does not occur retching conditions (number 0) has a greater percentage than granisetron-dexamethasone in both parameters of frequency and severity at $94 \%$ and $86 \%$. It shows that the incidence of vomiting without spending any less frequent in the combination of ondansetron and dexamethasone than granisetron and dexamethasone. Granisetron and dexamethasone group show experienced a frequency of vomiting without removing any of $7 \%$ for mild retching conditions (figure 1) and the conditions were retching (figure 2). It is also common in severity parameters. But at the ondansetron-dexamethasone group showed only mild retching (figure 1) by $6 \%$.

Profile vomiting table 4 describes that granisetrondexamethasone group responded better than the antiemetic ondansetron-dexamethasone group. The condition does not occur vomiting (number 0) granisetron-dexamethasone group showed $93 \%$ whereas ondansetron-dexamethasone group showed $88 \%$. Figures 1, which means mild vomiting occurs have the highest percentage in the ondansetron-dexamethasone group compared with the group granisterondexamethasone, which is $12 \%$ and $7 \%$. Further analysis will be done based on measurements INVR category breakdown showing the picture of the effectiveness of the condition of nausea and vomiting in each group ondansetron-dexamethasone and granisetron-dexamethasone group. INVR category level is divided into five categories based on the condition of nausea and vomiting value range. Category condition does not occur nausea and vomiting expressed by the absolute value of 0 . Category mild nausea and vomiting conditions for INVR value between 1-8. Category condition of nausea and vomiting was to INVR value between 9-16. Category severe nausea and vomiting conditions for INVR value between 17-24. And in the 
category of very severe nausea and vomiting conditions for INVR value between 24-32. Figure 1 shows that the condition does not occur nausea and vomiting ondansetron-dexamethasone group was $53 \%$ and granisetron-dexamethasone group by $79 \%$. This indicates that the granisetron group-dexamethasone can suppress nausea and vomiting response is greater than ondansetron-dexamethasone group.

From the Mann-Whitney analysis (Figure 1) showed that the combination of granisetron and dexamethasone was no difference in effectiveness in reducing nausea and vomiting than the acute phase of a combination of ondansetron and dexamethasone on pasein chemotherapy with a high risk of nausea and vomiting ( $\mathrm{p}=$ 0.076). From some research on the comparative effectiveness of ondansetron and granisetron in combination with dexamethasone or not, gives a different picture. $3 \mathrm{mg}$ granisetron and ondansetron $8 \mathrm{mg}$ in combination with dexamethasone have the same effectiveness in preventing nausea and vomiting due to cisplatin doses> $50 \mathrm{mg} / \mathrm{m} 3$, but ondansetron is more cost-effective than granisetron (Italian Group antiemetics Research 1995). According to the Italian Group antiemetics Research, granisetron combination with dexamethasone is more effective for preventing chemotherapy-induced nausea and vomiting risk of nausea and vomiting were compared with the use of dexamethasone or granisetron alone (Italian Group antiemetics Research, 1995). From the results of a metaanalysis of studies comparing several drugs 5-HT3 receptor antagonist for prophylaxis of acute nausea and vomiting due to chemotherapy. Combination chemotherapy-risk chemotherapy nausea and vomiting medium-high risk of nausea and vomiting with or without cisplatin demonstrated that granisetron has the same effectiveness with ondansetron. But at subanalisis i.v $3 \mathrm{mg}$ granisetron compared with ondansetron $8 \mathrm{mg}$ iv with non-cisplatin chemotherapy demonstrated that granisetron is effective in reducing nausea and vomiting compared to ondansetron (Jordan et al 2007). According to Dempsey, a retrospective multicenter study, granisetron $1 \mathrm{mg}$ or $10 \mathrm{mg} / \mathrm{kg}$ and $32 \mathrm{mg}$ showed ondansetron was more effective than administration of ondansetron 8 $\mathrm{mg}$ in the prevention of acute nausea and vomiting phase cyclophosphamide therapy (Dempsey 2004). In another study also found that administration of granisetron plus dexamethasone proved to be more effective in controlling nausea and vomiting than the acute phase administration of granisetron only (Keyhanian 2012).

Furthermore, we want to know picture of the effectiveness of antiemetic ondansetron-dexamethasone and granisetron-dexamethasone based on the effect of each combination sitostatika (Figure 2), the visible result of the effectiveness of ondansetron-dexamethasone $(\mathrm{n}=12)$ and granisetron-dexamethasone balanced, suppression of nausea and vomiting was $66,7 \%$ in the category does not occur nausea, vomiting and $33.3 \%$ in the category of mild nausea and vomiting. In the combination of cisplatin-paclitaxel (Figure 3) provision of antiemetic granisetron and dexamethasone $(n=5)$ showed a good response, ie $100 \%$ did not experience nausea and vomiting while the administration of ondansetron and dexamethasone $(n=5)$ of events did not experience nausea and vomiting just by $20 \%$ and the remaining $80 \%$ experiencing mild nausea and vomiting.

\section{CONCLUSION}

In the acute phase of chemotherapy patients with a high risk of nausea and vomiting administration of granisetron and deksmetason showed no difference in effectiveness in reducing nausea and vomiting than the delivery of ondansetron and dexamethasone $(p=0.076)$.

\section{REFERENCES}

Aapro, M. 2004. Granisetron: An Update on its Clinical Use in the Management of Nausea and Vomiting. The Oncologist. Vol. 9, pp. 673-686.

Basch, E., Prestrud, A., Hesketh, P., Kris, M., Feyer, P., Somerfield, M., Chesney, M., Anne, C., Flaherty, A., Freuundlich, B., Morrow, G., Rao, K., Scharwartz, R., Lyman, G. 2011. Antiemetics: American Society of Clinical Oncology Clinical Practice Guideline Update. Journal of Oncology. Vol. 29, pp. 4189-4198.

Brearley, S., Clement, C., Molassiotis, A. 2008. A Review of Patient Self-Report Tool for Chemotherapy-Induced Nausea and Vomiting. Support Care Cancer. Springer. Vol. 16, pp. 12131229.

Demsey,C.L., Coop, A.J., Shillington, A., Farley, P.A., Erberhardt, D.R., O'Briant, S. 2004. Antiemetic effectiveness of ondansetron and granisetron in patient with breast cancer treated with cyclophosphamide. American Journal of Health-System Pharmacy. 61. pp. 781-786.

Hesketh, P., Gralla, R., Navari, R., Popovic, W., Strupp, J., Noy, J., Einhom, L., Ettinger, D., Bushnell, W., Friedman, C. 1998. Single-Dose Oral Granisetron Has Equivalent Antiemetic Efficacy to Intravenous Ondansetron for Highly Emetogenic Cisplatin-Based Chemotherapy. Journal of Clinical Oncology, Vol. 16, pp.1568-1573.

Hesketh, Paul J. 2008. Drug Therapy ChemotherapyInduced Nausea and Vomiting. The New England Journal of Medicine. Vol. 358, pp. 2482-2494. 
Jordan K, Hinke A, Grothey A. 2007 A meta-analysis comparing the efficacy of four 5-HT3-receptor antagonists for acute chemotherapy-induced emesis. Support Care Cancer

Keyhanian Sh., Taziki O., Saravi MM., Fotokian Z. 2012. A Randomized comparison of Granisetron Plus Dexamethason with Granisetron alone for the Control of Acute Chemotherapy-Induced Emesis and Nausea. IJHOSCR, Vol .3, No.2. pp. 27-30

Kim, Hee Tae., Choi, Moon B., Chin, Ji Hyun., Lee, Moo Song., Kim, Dong Hee., Noh, Gyu Jeong. 2007. The Reliability and Validity of the Rhodex Index of Nausea, Vomiting and Retching in Postoperative Nausea and Vomiting. Korean Journal Anesthesiol. Vol. 52. No 6, pp. 59-65.

Mahesh, R., Venkatesha, R., Pandi, P.V. 2004. Cancer chemotherapy-induced nausea and vomiting: role of mediators, development of drugs and treatment methods. Pharmazie. Vol. 60, pp. 83-96.
1Rhodes. Index of Nausea Vomiting and Retching. www.hyperemesis.org.

2Rhodes. 1996. RINVR

Rojas, C., Slusher, B. 2012. Pharmacological mechanisms of 5-HT3 and tachykinin NK1 receptor antagonism to prevent chemotherapy-induced nausea and vomiting. European Journal of Pharmacology. Vol 684, pp. 1-7.

Schnell, F. 2003. Chemotherapy-Induced Nausea and Vomiting: The Importance of Acute Antiemetic Control. The Oncologist. Vol. 8, pp. 187-198.

The Italian Group Antiemetic Research. 1995. Dexamethasone, Granisetron, or Both for The Prevention of Nausea and Vomiting During Chemotherapy for Cancer. The New England Journal of Medicine. Vol. 332, pp. 1-5.

Wood, J., Chapman, K., Eilers, J. 2011. Tools for Assessing Nausea, Vomiting, and Retching. Cancer Nursing. Vol. 34, pp. E14-E24. 